\title{
Téoros
}

Revue de recherche en tourisme

\section{Implications of Eutrophication for Lake Tourism in Québec}

\section{Julianna Priskin}

Volume 27, numéro 2, été 2008

URI : https://id.erudit.org/iderudit/1070798ar

DOI : https://doi.org/10.7202/1070798ar

Aller au sommaire du numéro

Éditeur(s)

Université du Québec à Montréal

ISSN

0712-8657 (imprimé)

1923-2705 (numérique)

Découvrir la revue

Citer cette note

Priskin, J. (2008). Implications of Eutrophication for Lake Tourism in Québec. Téoros, 27(2), 59-61. https://doi.org/10.7202/1070798ar d'utilisation que vous pouvez consulter en ligne.

https://apropos.erudit.org/fr/usagers/politique-dutilisation/ 


\section{Réseau de veille en tourisme - Chaire de tourisme Transat Implications of Eutrophication for Lake
Tourism in Québec}

\section{Julianna Priskin}

\section{Introduction}

Water is essential to the planet and its societies, yet, it is one of the scarcest resources globally today (Klessing, 2000; Jöbgen et al., 2004; Babou and Callot, 2007). According to the World Resources Institute (WRI, 2008), global water consumption increased sixfold in the last century and over $40 \%$ of the world's population lives in water poverty today. It is estimated that if present water use trends continue, two of every three humans will live in conditions of water stress worldwide by 2025. Water use affects all economic sectors including tourism, and the lack of it represents a major impediment to development (Rahm et al., 2006). In Québec, water quality rather than water availability is of greater concern particularly in lake regions. Lakes are complex and fragile ecosystems that form an important part of Québec's heritage and they are part of the quintessential tourism experience in some regions (Hade, 2002; Tourisme Québec, 2007). For some years now, many of the lakes heavily used by tourism and recreation have been suffering from algal outbreaks in Québec. In 2007, the propagation of blue-green algae resulted in over 200 lakes being declared off-limits to bathers, because of risks associated with eutrophication. In this context, the aim of this chronicle is to highlight how tourism and recreation are a part of the eutrophication problem in Québec, and outline some of the solutions that could be implemented to address this growing issue.

\section{Some Impacts of Eutrophication and Algal Blooms}

It is well accepted that tourism can exert particular pressure on water in all seasons at all destinations (Clivaz and Reynard, 2008). However, total water use by tourism is difficult to ascertain because the sector is diffuse and fragmented and, consequently, total impact is also hard to estimate. The average urban citizen in Québec uses 90 to 180 litres of water a day, while the average global use per tourist ranges from 100 to 2000 litres per day (Gössling, 2006). Water use by tourism is directly linked to operations of facilities and maintenance, as well as use by visitors for various activities such as to shower, swim in pools, and so on. For some activities and facilities, water use may even be much higher, for example ski stations that draw heavily on water for artificial snowmaking. Much of water consumption in tourism is also associated with chemical use such as detergents and soaps, which can be a significant source of pollution.
Furthermore, besides their damaging physical impacts, motorized activities on lakes also introduce various hydrocarbon compounds from fuels and anti-fouling paints (Mosisch and Arthington, 2004). The use of synthetic fertilizers and various chemical products by the tourism sector is common to maintain green spaces around establishments. For example, in Québec, 307 golf courses contribute approximately 40000 kilograms of active ingredients through fungicides, herbicides, and insecticides to ecosystems and the most severely impacted areas occur in the Montréal, Laurentides, and Lanaudière regions, which are all places of high lake concentration (Lavardière et al., 2007). Sewage outflow from diffuse small-scale tourism and recreation can be a singularly important source of bacteria and algae in freshwater systems in remote areas (Lukavsky et al., 2006), although their contribution has not been established in Québec, especially around outfitter camps and resorts.

The impact of pollution such as eutrophication on water quality is dependent on lake characteristics, intensity and type of pollution, as well as management regimes, amongst other factors. Furthermore, eutrophication is partially a natural process as lakes age and become nutrient rich. This transformation process is affected by the biophysical and chemical characteristics of an individual lake, as well as by the hydrogeology and land use pattern of its watershed (Salmaso, 2000; Davies and Koop, 2006). An excessive introduction of nutrients by humans has lead to severe eutrophication of certain freshwater systems worldwide (Gössling, 2006; Davis, 2007; WRI, 2008). Impacts of eutrophication often mean excessive growth of phytoplankton and algae, changes in species abundance and composition, biomass production and dissolved oxygen content. Some lakes can become eutrophic to the point of hypoxia because their ecosystem gets completely depleted of oxygen. Eutrophication is also associated with various health risks to humans and a general loss of lake amenity caused by unpleasant smells and reduced water clarity (Larkin and Adams, 2007; Health Canada, 2008).

In Europe and in North America, agricultural sources are generally the primary contributors to eutrophication, while sewage and industrial sources are secondary (Cronberg, 1999; McGarrigle and Champ, 1999). In Québec, agriculture, deforestation, human sewage, urban and industrial run-off are common sources, but it varies in different regions. In certain lake areas of Europe and North America, visitors and secondary residential users are known to be the most 
important contributors to lake eutrophication (Jöbgen et al., 2004; Weible, 2007). However, in Québec there is not sufficient information to date to determine exact contributions of this sector. Certainly the high proportion of secondary homes present in lakeshore areas of the Province that have septic tanks is an important contributor, because these retain only a percentage of their waste volume (Hade, 2002). Up to $25 \%$ of waste from septic tanks seep into the soil and the groundwater, and, depending on its location, eventually enter a lake.

Algal blooms can also be natural, but once a lake becomes eutrophic, it can trigger rapid growth of certain harmful algae types (Cronberg, 1999; Salmaso, 2000; Larkin and Adams, 2007). Bluegreen algae or cynobacteria are known as the most common harmful algae in freshwater lakes, reservoirs, and slow-flowing rivers. In many cases they remain dormant, unless conditions for their reproduction become favourable. Algae can increase for many reasons, and nutrient-loading change is but one mechanism (Anderson et al., 2002). There can be a significant time lag between waste production and eventual groundwater or lake water contamination. In some places, the observed algal areas have been linked to heavy fertilizer use up to 10 to 20 years prior to the outbreak (Anderson et al., 2002; Shear, 2006).

Eutrophic ecosystems and those affected by algae outbreaks have a diminished capacity to provide services to society and this can significantly influence communities that rely on water for their livelihoods (Selman et al., 2008). In Australia, algal blooms in freshwater systems cost the community from 180 to 240 million AUD every year. Research from the United States suggest that this effect is not similar on every business and a study in Florida showed that algal blooms in coastal waters affected monthly revenues of waterfront businesses, resulting in 29\% and 35\% net reductions for the restaurant and lodging sectors respectively. The total net economic effect of diminished lake water quality in Québec has not been calculated, however it would be variable. This is likely to depend on many factors, including the relative size of the expenditures for tourism activities linked to lake use. The diversified nature of Québec's tourism industry may also mean that the loss of revenue in one area might result in a net gain in another, because tourists simply redirect their activities in a situation of available alternatives (Hoagland et al., 2002). Given the proliferation of tourism products in Québec, and elsewhere, tourists will continue to have alternatives. However, residents and economic activities reliant on lakes will need to address the consequences of continued eutrophication.

\section{Possible Mitigation Measures}

It is not clearly established how either tourism or recreation contribute, compared to other land uses, to lake eutrophication in Québec. It is also not clear how much lakes contribute to tourism economics in different regions. Thus it would be important to understand the relationship between lakes and tourism to enable problem mitigation involving the tourism industry (McGarrigle and Champ, 1999; Davis and Koop, 2006). An adequate long-term preventative approach at the watershed scale and the use of appropriate management tools are therefore required (Jorgensen and Rast, 2007). Tourism is often not included as a major land use when it comes to stakeholder management groups, because it is diffuse and it is often perceived to be harmless. Yet, tourism is an important water resources user amongst residents and other industry sectors. In this context it is thus important that the tourism industry adopts a sense of ownership over the natural resources it exploits (Sheppard et al., 2006).

Environmental restoration of lakes is expensive and complex, given that several organizations may have legal jurisdiction over them (Bramwell and Pomfrett, 2007). There are several examples of successful restoration projects in Québec involving collaborative work between the tourism industry, government, and non-government organizations (Tourisme Québec, 2000). Some of these projects include riparian vegetation planting and the development of recreation activities and infrastructures around lakes. Other management actions, such as planting aquatic species to increase natural filtering mechanisms, may also be pertinent in some lakes, because these absorb additional nutrient loads (Jöbgen et al., 2004). While such interventions are considered effective to mitigate eutrophication, the physical presence of plants in lakes has been reported to be a nuisance to recreational swimmers and boating in the Netherlands (Coops et al., 2002).

One of the most effective ways to address environmental management problems is to prevent them from occurring initially, and this can be achieved by raising awareness via education. Various public sector and non-government organizations recommend more efficient use of water resources for the tourism sector and the elimination of toxic substances. Awareness programs such as the Charte des lacs (MDDEP, 2008b) in Québec are important tools to help educate the population, improve water use, and reduce pollution (McGarrigle and Champ, 1999). Some tourism businesses have switched from using toxic substances in their operations and replaced polluting products with biodegradable alternatives. However, the extent of change across the whole sector has not been determined.

In order to involve the tourism industry and tourists more in environmental management programs, it would also be important to determine their perceptions and attitudes to lakes and water resources in Québec. General perceptions of environmental quality can be surprising, even when community livelihood is water dependent (Varkuti et al., 2008). For example, in a study of permanent residents around an important lake tourism destination in Hungary, researchers found that only $43.3 \%$ considered water quality important to recreation and only $13.3 \%$ considered it important to the economic well-being of the region.

Regulation can also be an effective tool to address water quality problems around lakes and the Government of Québec has implemented a range of measures recently. The use of pesticides, herbicides, and insecticides is regulated, although various land uses are affected differently. Since 2006, legislation no longer permits pesticide use on lawns and public green spaces, including semi-public areas and places managed by municipalities (MDDEP, 2008a). Consequently, particular users in the tourism sector such as golf 
courses are now required to submit a plan to reduce their use of pesticides by 2009 by $12.9 \%$ on average, fungicides by $9.4 \%$, herbicides by $8.2 \%$, and insecticides by $7.4 \%$.

\section{Conclusion}

This chronicle briefly highlighted some of the relationships between tourism and lakes. Québec's tourism sector relies on lakes and continued eutrophication of these ecosystems may have negative impacts on this industry. The competition for freshwater resources will likely to intensify in the future and climate change will also affect lakes in Canada (Jones et al., 2006). These may have important impacts for tourism in Québec and, consequently, some monitoring of key indicators would be useful to help adapt to changing resource conditions. Very limited knowledge is available presently about lake tourism in Québec; therefore, more research would be important to establish some basic facts aimed at more effective decision-making.

Julianna Priskin est professeure associée au Département d'études urbaines et touristiques de I'UQÀM et chercheure à la Chaire de Tourisme Transat de la même université.

\section{Bibliographie}

Anderson, D.M., P.M. Glibert, and J.M. Burkholder (2002), " Harmful Algal Blooms and Eutrophication: Nutrient Sources, Composition, and Consequences », Estuaries, vol. 25, no. 4, p. 704-726.

Babou, I. and P. Callot (2007), Les dilemmes du tourisme, Vuibert, Paris.

Bramwell, B. and G. Pomfret (2007), "Planning for Lake and Lake Shore Tourism: Complexity, Coordination and Adaptation ", International Journal of Tourism and Hospitality Research, vol. 18, no. 1, p. 43-66.

Clivaz, C. and E. Reynard (2008), " Crans-Montana: Water Resources Management in an Alpine Tourist Resort ", dans E. Wiegandt (dir.), Mountains: Sources of Water, Sources of Knowledge. Advances in Global Change Research, vol. 31. Springer Netherlands, p. 103-119.

Coops, H., E.H. van Nes, M.S. van den Berg, and G.D. Butijn (2002), "Promoting Low-Canopy Macrophytes to Compromise Conservation and Recreational Navigation in a Shallow Lake ", Aquatic Ecology, vol. 36, p. 483-492.

Cronberg, G. (1999), "Qualitative and Quantitative Investigations of Phytoplankton in Lake Ringsjön, Scania, Sweden ", Hyrobiologia, no. 404, p. 27-40.

Davis, C. (2007), The Multiple Dimensions of Water Scarcity. EarthTrends. World Resources Institute.

Davis, J.R. and K. Koop (2006), "Eutrophication in Australian Rivers, Reservoirs and Estuaries - Southern Hemisphere Perspective on the Science and its Implications ", Hydrobiologia, vol. 559, p. 23-76.

Gössling, S. (2006), "Tourism and Water », dans S. Gössling and C.M. Hall (dir.), Tourism and Global Environmental Change: Ecological, Social, Economic, and Political Interrelationships, Routledge, Londres, p. 180194.

Hade, A. (2002), Nos lacs : les connaître pour mieux les protéger, Fides, Québec.

Health Canada (2008), Blue-Green Algae (Cyanobacteria) and their Toxins, [http://www.hc-sc.gc.ca/ewh-semt/pubs/water-eau/cyanobacter_e. html], consulté le 2 mai 2008.

Hoagland, P., D.M. Anderson, Y. Kaoru, and A.W. White (2002), "The Economic Effects of Harmful Algal Blooms in the United States: Estimates, Assessment Issues and Information Needs ", Estuaries, vol. 25, no. 4, p. 819-837.

Jöbgen, A.M., A. Palm, and M. Melkonian (2004), « Phosphorus Removal from Eutrophic Lakes Using Periphyton on Submerged Artificial Substratal », Hydrobiologia, vol. 528, p. 123-142.
Jones, B.E., D. Scott, and S. Gössling (2006), "Lakes and Streams ", dans S. Gössling and C.M. Hall (dir.), Tourism and Global Environmental Change: Ecological, Social, Economic, and Political Interrelationships, Routledge, Londres, p. 67-94.

Jorgensen, S.E. and W. Rast (2007), « The Use of Models for Synthesizing Knowledge for Integrating Lake Basin Management, and Facilitating Implementation of the World Lake Vision ", Lakes and Reservoirs: Research and Management, vol. 12, p. 3-13.

Klessing, L.L. (2001), "Lakes and Society: the Contribution of Lakes to Sustainable Societies ", Lakes and Reservoirs: Research and Management, vol. 6, p. 95-101.

Larkin, S.L. and C.M. Adams (2007), " Harmful Algal Blooms and Coastal Business: Economic Consequences in Florida ", Society and Natural Resources, vol. 20, p. 849-859.

Lavardière, C, S. Dion, and S. Gauthier (2007), Bilan des plans des réductions des pesticides sur les terrains de golf au Québec, Rapport réalisé pour le ministère du Développement durable, de l'Environnement et des Parcs, Gouvernement du Québec.

Lukavsky, J., A. Moravcova, L. Nedbalova, and O. Rauch (2006), "Phytobenthos and Water Quality in Mountain Streams in the Bohemian Forest Under the Influence of Recreational Activity ", Biologia, vol. 61 (Suppl. 20), p. S533-S542.

McGarrigle, M.L. and W.S.T. Champ (1999), "Keeping Pristine Lakes Clean: Loughs Conn and Mask, Western Ireland ", Hydrobiologia, vol. 395396, p. 455-469.

Ministère du Développement durable, de l'Environnement et des Parcs (MDDEP) (2008a), Actions ministérielles en matière de pesticides, [www. mddepp.gouv.qc.ca/pesticides/actions.htm], consulté le 28 avril 2008.

Ministère du Développement durable, de l'Environnement et des Parcs (MDDEP) (2008b), Charte des lacs, [www.menv.gouv.qc.ca/eau/ algues-bv/engagement/engagement.asp], consulté le 2 mai 2008.

Mosisch, T.D. and A.H. Arthington (2004), " Impacts of Recreational Powerboating on Freshwater Ecosystems », In R. Buckley (dir.), Environmental Impacts of Ecotourism, Wallingford, CABI Publishing, p. 125-154.

Rahm, D., L. Swatuk, and E. Matheny (2006), « Water Resource Management in Botswana: Balancing Sustainability and Economic Development ", Environment, Development and Sustainability, vol. 8, p. 157-183.

Salmaso, N. (2000), «Factors Affecting the Seasonality and Distribution of Cyanobacteria and Chlorophytes: A Case Study from Large Lakes South of the Alps, with Special Reference to Lake Garda ", Hydrobiologia, vol. 438, p. 43-63.

Selman, M. et al. (2008) "Eutrophication and Hypoxia in Coastal Areas: A Global Assessment of the State of Knowledge ", World Resources Institute Policy, note 1, p. 1-6.

Shear, H. (2006), "The Great Lakes, an Ecosystem Rehabilitated, but Still under Threat ", Environmental Monitoring and Assessment, vol. 113, p. 199-225.

Sheppard, P., J. Tansey, and H. Dowlatabadi (2006), " Context Matters: What Shapes Adaptation to Water Stress in the Okanagan? ", Climate Change, vol. 78, p. 31-62.

Tourisme Québec (2000), Guide de mise en valeur des plans d'eau du Québec à des fins récréotouristiques et de conservation du patrimoine, Groupe DBSF pour Tourisme Québec.

Tourisme Québec (2007), Le Québec grande nature. Plan intégré par expérience : Diagnostic et orientations, Ministère du tourisme du Québec.

Várkuti, A., K. Kovács, C. Stenger-Kovács, and J. Padisák (2008), "Environmental Awareness of the Permanent Inhabitants of Towns and Villages on the Shores of Lake Balaton with Special Reference to Issues Related to Global Climate Change ", Hydrobiologia, vol. 599, p. 249257.

Weible, C.M. (2007), "Stakeholder Perceptions of Scientist: Lake Tahoe Environmental Policy from 1984-2001 ", Environmental Management, vol. 40, p. $853-865$.

World Resources Institute (2008), Water Resources and Freshwater Ecosystems, [http://earthtrends.wri.org/features/index.php?theme=2], consulté le 2 mai 2008. 